\title{
Epstein-Barr virus (EBV) reactivation is a frequent event after allogeneic stem cell transplantation (SCT) and quantitatively predicts EBV-lymphoproliferative disease following T-cell-depleted SCT
}

Joost W. J. van Esser, Bronno van der Holt, Ellen Meijer, Hubert G. M. Niesters, Rudolf Trenschel, Steven F. T. Thijsen, Anton M. van Loon, Francesco Frassoni, Andrea Bacigalupo, Ulrich W. Schaefer, Albert D. M. E. Osterhaus, Jan Willem Gratama, Bob Löwenberg, Leo F. Verdonck, and Jan J. Cornelissen

Reactivation of the Epstein-Barr virus (EBV) after allogeneic stem cell transplantation (allo-SCT) may evoke a protective cellular immune response or may be complicated by the development of EBV-lymphoproliferative disease (EBV-LPD). So far, very little is known about the incidence, recurrence, and sequelae of EBV reactivation following alloSCT. EBV reactivation was retrospectively monitored in 85 EBV-seropositive recipients of a T-cell-depleted (TCD) allo-SCT and 65 EBV-seropositive recipients of an unmanipulated allo-SCT. Viral reactivation (more than $50 \mathrm{EBV}$ genome equivalents $[\mathrm{gEq}] / \mathrm{mL}$ ) was monitored frequently by quantitative realtime plasma polymerase chain reaction until day 180 after SCT. Probabilities of developing viral reactivation were high after both unmanipulated and TCD-allogeneic SCT ( $31 \% \pm 6 \%$ versus $65 \% \pm 7 \%$, respectively). A high $\mathrm{CD}_{34}{ }^{+}$cell number of the graft appeared as a novel significant predictor $(P=.001)$ for EBV reactivation. Recurrent reactivation was observed more frequently in recipients of a TCD graft, and EBV-LPD occurred only after TCD-SCT. High-risk status, TCD, and use of antithymocyte globulin were predictive for developing EBV-LPD. Plasma EBV DNA quantitatively predicted EBV-LPD. The positive and negative predictive values of a viral load of $1000 \mathrm{gEq} / \mathrm{mL}$ were, respectively, $39 \%$ and $100 \%$ after TCD.
Treatment-related mortality did not differ significantly between TCD and non-TCD transplants, but the incidence of chronic graftversus-host disease was significantly less in TCD patients. It is concluded that EBV reactivation occurs frequently after TCD and unmanipulated allo-SCT, especially in recipients of grafts with high CD34+ cell counts. EBV-LPD, however, occurred only after TCD, and EBV load quantitatively predicted EBVLPD in recipients of a TCD graft. (Blood. 2001;98:972-978)

๑) 2001 by The American Society of Hematology

\section{Introduction}

Epstein-Barr virus-associated lymphoproliferative disease (EBVLPD) is a serious complication of allogeneic stem cell transplantation (allo-SCT) and solid-organ transplantation. ${ }^{1-3}$ Although the incidence of EBV-LPD is generally less than $2 \%$ after allo-SCT, it may increase to $20 \%$ in patients with established risk factors, such as unrelated donor SCT, the use of T-cell-depleted (TCD) allografts, use of antithymocyte globulin (ATG), and immunosuppression for prevention and treatment of graft-versus-host disease (GVHD) ${ }^{4-8}$ EBV-LPD is associated with a poor prognosis despite the use of anti-B-lymphocyte monoclonal antibody therapy, ${ }^{9-12}$ donor lymphocyte infusion (DLI), ${ }^{13}$ and infusion of EBV-specific cytotoxic T cells. ${ }^{14,15}$ Therefore, early diagnosis and preventive measures, such as B-cell depletion of the donor graft, ${ }^{4,7,16}$ and pre-emptive therapy may be clinically useful. ${ }^{17-24}$

We developed a real-time polymerase chain reaction (PCR) assay for the quantitative detection of EBV-DNA in plasma. ${ }^{25}$ The assay accurately monitors viral load in plasma from patients with infectious mononucleosis and immunocompromised patients at risk of EBV-LPD or with established EBV-LPD..$^{25,26}$ In contrast to cytomegalovirus (CMV) antigenemia after allo-SCT and the risk of developing CMV disease, little is known about reactivation of EBV during the first 3 to 6

From the Departments of Hematology, Statistics, Virology, and Medical and Tumor Immunology, University Hospital Rotterdam/Daniel den Hoed Cancer Center, The Netherlands; Departments of Hematology and Virology, University Medical Center Utrecht, The Netherlands; Clinic of Bone Marrow Transplantation, University Hospital Essen, Germany; and Department of Hematology, Ospedale San Martino, Genoa, Italy. months after allo-SCT and the predictive value of EBV reactivation for subsequent EBV-LPD. Although several studies have shown an association between viral load and a diagnosis of EBV-LPD, ${ }^{27-43}$ no study has longitudinally followed a larger cohort of allo-SCT recipients with multiple risk factors. We set out to monitor EBV reactivation by real-time PCR at regular intervals after allo-SCT. Incidences, risk factors, and sequelae of EBV reactivation were compared between patients receiving a TCD-SCT and patients having transplantation with an unmanipulated stem cell graft. We show that subclinical EBV reactivation is a very frequent event after allo-SCT and that quantification of EBV-DNA appears useful to identify patients at risk of progression to overt EBV-LPD.

\section{Patients and methods}

\section{Patients}

The study population consisted of 152 consecutive patients treated at 4 transplant centers, who received stem cell transplants between March 1996 and June 1999. Patients underwent allografting at the department of hematology of the university hospitals of Utrecht (TCD-SCT) or Rotterdam

Reprints: Jan J. Cornelissen, Department of Hematology, University Hospital Rotterdam/Daniel den Hoed Cancer Center, Groene Hilledijk 301, 3075 EA Rotterdam, The Netherlands; e-mail: cornelissen@hemh.azr.nl.

The publication costs of this article were defrayed in part by page charge payment. Therefore, and solely to indicate this fact, this article is hereby marked "advertisement" in accordance with 18 U.S.C. section 1734

(c) 2001 by The American Society of Hematology 
(TCD-SCT), The Netherlands; Essen (non-TCD-SCT), Germany; or Genoa (non-TCD-SCT), Italy. Transplant protocols were approved by local institutional review boards, and all patients provided informed consent. Patient characteristics are presented in Table 1. Eighty-five patients received a TCD-SCT and 67 patients received a non-TCD-SCT. Median age was 41 years (range, 17-55 years) in the TCD group and 31 years (range, $17-56$ years) in the non-TCD group $(P<.01)$. Standard-risk patients had a diagnosis of acute lymphoblastic leukemia (ALL) in first complete remission (CR1), acute myeloid leukemia (AML) in CR1, chronic myeloid leukemia (CML) in first chronic phase, and untreated (very) severe aplastic anemia (SAA). All other diagnoses were considered high risk. The non-TCD group included more patients with CML and fewer patients with lymphoma, multiple myeloma, or high-risk disease $(P=.001)$. Unrelated donor grafts were used more frequently in the non-TCD group $(P=.001)$. The use of ATG added to the conditioning regimen for prevention of

Table 1. Patient characteristics

\begin{tabular}{|c|c|c|c|}
\hline Characteristic & $\begin{array}{c}\text { Allogeneic } \\
\text { T-cell-depleted } \\
\text { SCT }(n=85)\end{array}$ & $\begin{array}{l}\text { Allogeneic non-T-cell- } \\
\text { depleted SCT }(n=67)\end{array}$ & $P$ \\
\hline Sex male/female $(\mathrm{n})$ & $48 / 37$ & $50 / 17$ & .02 \\
\hline Age, y (median, range) & $41(17-55)$ & $31(17-56)$ & $<.01$ \\
\hline \multicolumn{4}{|l|}{ Diagnosis $(n)$} \\
\hline AML CR1 & 11 & 3 & \\
\hline $\mathrm{AML}>\mathrm{CR} 1$ & 8 & 8 & \\
\hline ALL CR1 & 5 & 6 & \\
\hline $\mathrm{ALL}>\mathrm{CR} 1$ & 7 & 2 & \\
\hline ALL CR1 $\mathrm{Ph}^{+}$ & 5 & - & \\
\hline MDS & 3 & 1 & \\
\hline CML CP1 & 8 & 28 & \\
\hline $\mathrm{CML}>\mathrm{CP} 1$ & 5 & 16 & \\
\hline SAA & 5 & - & \\
\hline MM & 15 & 1 & \\
\hline M. Hodgkin & 2 & - & \\
\hline $\mathrm{NHL}$ & 10 & 2 & \\
\hline CLL & 1 & - & \\
\hline Risk status: SR/HR (n) & $25 / 60$ & $37 / 30$ & .001 \\
\hline \multicolumn{4}{|l|}{ Donor type $(n)$} \\
\hline Sib & 61 & 30 & .001 \\
\hline MUD & 24 & 37 & \\
\hline \multicolumn{4}{|l|}{ Conditioning regimen $(n)$} \\
\hline $\mathrm{Cy} / \mathrm{TBI}$ & 59 & 67 & \\
\hline Cy/TBI/ATG & 23 & - & \\
\hline $\mathrm{Bu} / \mathrm{Cy}$ & 2 & - & \\
\hline $\mathrm{Bu} / \mathrm{Cy} / \mathrm{ATG}$ & 1 & - & \\
\hline \multicolumn{4}{|l|}{$\begin{array}{l}\text { Graft characteristics } \\
\text { (median, range) }\end{array}$} \\
\hline $\mathrm{MNC} \times 10^{8} / \mathrm{kg}$ & $0.13(0.01-9.32)$ & $3.43(0.13-14.0)$ & \\
\hline $\mathrm{CD} 3 \times 10^{5} / \mathrm{kg}$ & $2.0(1.0-7.5)$ & $510(7.4-2195)$ & $<.001$ \\
\hline CFU-GM × 104/kg & $16.7(1.9-85.9)$ & $14.1(4.0-132)$ & .6 \\
\hline CD34 × 106/kg & $1.25(0.06-6.43)$ & $2.2(0.04-14.1)$ & .7 \\
\hline \multicolumn{4}{|l|}{ EBV serology (n) } \\
\hline D-R- & - & 2 & .2 \\
\hline $\mathrm{D}+\mathrm{R}-/ \mathrm{D}+\mathrm{R}+/ \mathrm{D}-\mathrm{R}+$ & 85 & 65 & \\
\hline \multicolumn{4}{|l|}{ Stem cell source $(n)$} \\
\hline $\mathrm{BM}$ & 66 & 63 & $<.01$ \\
\hline PB & 19 & 4 & \\
\hline
\end{tabular}

AML1 CR1 or $>$ CR1 indicates acute myeloid leukemia in first or subsequen complete remission; ALL CR1 or $>$ CR1, acute lymphoblastoic leukemia in first or subsequent CR; ALL CR1 $\mathrm{Ph}^{+}$, ALL CR1 Philadelphia chromosome-positive; MDS, myelodysplastic syndrome; CML CP1 or > CP1, chronic myeloid leukemia in first or subsequent chronic phase; SAA, severe aplastic anemia; MM, multiple myeloma; NHL, non-Hodgkin lymphoma; CLL, chronic lymphocytic leukemia; SR, standard risk; HR, high risk; Sib, HLA-identical family donor; MUD, matched unrelated donor; Cy, cyclophosphamide; TBI, total-body irradiation; Bu, busulfan; ATG, antithymocyte globulin; MNC, mononuclear cells; CFU-GM, granulocyte-macrophage colony-forming unit; $D+/-$, Epstein-Barr virus (EBV)-seropositive/seronegative donor; $\mathrm{R}+/$-, EBV-seropositive/seronegative recipient; BM, bone marrow; PB, peripheral blood. rejection was confined to patients having transplantation with TCD grafts from unrelated donors.

\section{Transplantation}

The conditioning regimen preceding a TCD-SCT consisted of cyclophosphamide $(120 \mathrm{mg} / \mathrm{kg})$ and total-body irradiation (TBI) (12 Gy in 2 fractions). Rabbit ATG (Imtix Sangstat, Amstelveen, The Netherlands) was given for prevention of rejection before SCT in recipients of a TCD unrelated donor graft. If patients had previously been treated with locoregional irradiation, the conditioning regimen consisted of oral busulfan $(4 \mathrm{mg} / \mathrm{kg}$ on each of 4 successive days) and cyclophosphamide $(120 \mathrm{mg} / \mathrm{kg})$. The conditioning regimen in case of an unmanipulated SCT consisted of cyclophosphamide $(120 \mathrm{mg} / \mathrm{kg}$ ) and TBI (10 Gy in 4 or 3 fractions).

Partial T-cell depletion was performed using sheep erythrocyte rosetting $(\mathrm{n}=53)$ or CD34 selection (Cellpro, Wezembeek, Belgium) $(\mathrm{n}=32)$. Median T-cell numbers differed more than 2 logs between TCD and unmanipulated grafts $\left(2.0 \times 10^{5} / \mathrm{kg}\right.$ versus $\left.510 \times 10^{5} / \mathrm{kg}\right)$, but numbers of granulocyte-macrophage colony-forming units (CFU-GMs) and $\mathrm{CD} 34^{+}$ mononuclear cells (MNCs) did not differ significantly between the groups of patients. Peripheral blood-derived stem cells were used relatively more often than bone marrow-derived stem cells in patients receiving a TCD graft as compared with patients receiving an unmanipulated graft $(P<.01)$. Graft-versus-host $(\mathrm{GVH})$ prophylaxis was cyclosporin A $(3 \mathrm{mg} / \mathrm{kg})$ from day -3 until day +100 after TCD-SCT, and the combination of methotrexate $\left(15 \mathrm{mg} / \mathrm{m}^{2}\right.$ on day $1 ; 10 \mathrm{mg} / \mathrm{m}^{2}$ on days 3,6 , and 11$)$ and cyclosporin A was used in recipients of an unmanipulated SCT.

All patients received ciprofloxacin and fluconazole for prevention of infection during neutropenia, and cotrimoxazole was given after neutrophil recovery until days 180 to 360 after SCT. Patients having transplantation in Utrecht (TCD-SCT) and Genoa (non-TCD-SCT) received long-term acyclovir prophylaxis from day 0 until day 360. Erythrocyte and platelet products for transfusion were filtered to remove leukocytes and subsequently irradiated (25 Gy). Patients were hospitalized in reverse isolation in rooms with high-efficiency particulate-filtered air. All patients received food with a low microbial count until discharge, and parenteral alimentation was given in case of severe mucositis.

\section{Real-time Taqman assay}

Taqman PCR primers were selected from the EBV-DNA genome encoding for the nonglycosylated membrane protein BNRF1-p143 and generated a DNA product of 74 base pairs, as described before.$^{25} \mathrm{~A}$ known EBV-DNA copy number based on a reference standard quantified by electron microscopy (ABI Advanced Biotechnologies, Columbia, MA) was used for standardization. Serial dilutions ranging from 10 to $10^{7} \mathrm{EBV}-\mathrm{DNA}$ genome equivalents per milliliter $(\mathrm{gEq} / \mathrm{mL})$ were made to characterize linearity, precision, specificity, and sensitivity. The Taqman assay appeared to detect viral DNA in plasma over a linear span between 50 and $10^{7} \mathrm{gEq} / \mathrm{mL}$, with an average coefficient of variation of $1.56 \%$ (range, $0.7 \%$ to $7.0 \%$ ). Test results below $50 \mathrm{gEq} / \mathrm{mL}$ were considered negative. No viral DNA was detected in plasma of healthy EBV-seropositive individuals. ${ }^{25} \mathrm{EBV}$ reactivation was defined as a plasma EBV-DNA level exceeding $50 \mathrm{gEq} / \mathrm{mL}$. Recurrent reactivation was defined by a positive PCR (more than 50 $\mathrm{gEq} / \mathrm{mL}$ ) after (at least) 2 consecutive negative PCR results following a preceding episode of reactivation. Viral load was monitored in blood samples drawn at 2-week intervals starting at SCT until day 180 after SCT.

\section{EBV-LPD diagnosis}

A diagnosis of EBV-LPD was preferably based on lymph node histology or cytology and was classified according to the criteria of Knowles et al. ${ }^{44}$ Immunohistology included antibody staining with CD19-specific (Becton Dickinson, San Jose, CA), CD20-specific (Dako, Glostrup, Denmark), and EBV latent membrane protein-1-specific (Dako) monoclonal antibodies. Furthermore, clonality was assessed using immunohistochemical staining with monoclonal antibodies to kappa and lambda light chains (Dako). In situ hybridization was performed to detect EBV-encoded small RNA molecules (EBV-EBER) using an EBV-EBER probe (Dako) and PCR for 


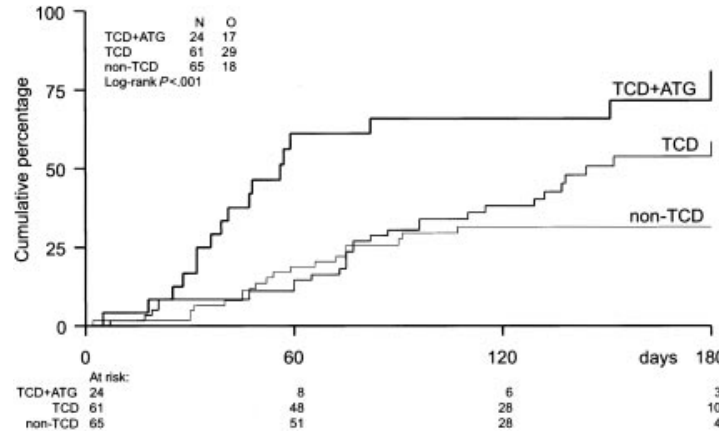

Figure 1. Incidence of EBV reactivation. Incidence of EBV reactivation after TCD-allogeneic SCT with ATG $(n=24)$, TCD-SCT without ATG $(n=61)$, and non-TCD-SCT $(n=65)$. Only TCD combined with ATG significantly increased the risk of EBV reactivation $(P<.001)$

detection of EBV-DNA encoding for the BamHI fragment. EBV-LPD staging included physical examination, whole-body computed tomography (CT) scanning, and flow cytometric detection of monoclonal B lymphocytes in blood, bone marrow, and, if indicated, cerebrospinal fluid.

\section{End points and statistical analysis}

The data were analyzed as of January 2000. Patient characteristics of non-TCD patients and TCD patients were compared using Fisher exact test or Pearson chi-square test, whichever was appropriate, in case of discrete variables, or the Wilcoxon rank-sum test in case of continuous variables. End points of the study included time to EBV reactivation, EBV-LPD, acute GVHD grades II to IV, chronic GVHD, and treatment-related mortality (TRM). Time to first EBV reactivation was determined from the date of transplantation until day 180, and patients were censored at the date of last serum sample if this sample had been taken before day 180. Time to EBV-LPD was measured from SCT until EBV-LPD. Patients who died without EBV-LPD were censored at the date of death. Patients still alive at the date of analysis were censored at the last follow-up date. Two EBV-seronegative donor-recipient pairs were excluded from the analysis of EBV reactivation and EBV-LPD. GVHD was diagnosed and graded according to consensus criteria. ${ }^{45}$ Chronic GVHD was evaluated among patients who survived at least 100 days after transplantation. TRM was defined according to standard criteria. ${ }^{46}$ Time to EBV reactivation, EBVLPD, acute and chronic GVHD, and TRM were estimated by the Kaplan-Meier method, and Kaplan-Meier curves were generated to illustrate differences between subgroups of patients. ${ }^{47}$ The following variables were included in the analysis of prognostic factors: sex, male patient and female donor, age, risk status, donor (sibling versus matched unrelated donor), source of stem cells (bone marrow versus peripheral blood), type of transplant (non-TCD versus TCD without ATG versus TCD with ATG), and graft characteristics (number of MNCs, number of $\mathrm{CD} 34^{+}$cells, number of $\mathrm{CD}^{+}$and CFU-GMs infused). Univariate survival analysis was performed using the log-rank test and Cox regression to see whether there was a difference between subgroups. ${ }^{48,49}$ The variables that appeared significant in the univariate analysis were also included in a multivariate Cox regression. Moreover, Cox regression was performed using EBV reactiva- tion within day 180 as a time-dependent covariate to assess whether EBV reactivation predicted EBV-LPD and TRM. All reported $P$ values are 2-sided, and a significance level of $\alpha=.05$ was used.

\section{Results}

\section{EBV reactivation}

The probability of developing EBV reactivation was greater after TCD-allogeneic SCT than after non-TCD-SCT (Figure 1, Table 2). That difference, however, could be largely attributed to the use of ATG in conjunction with TCD (Figure 1, Table 3). Probabilities of viral reactivation were not different between recipients of a non-TCD-SCT and recipients of a TCD-SCT without concomitant ATG. Median time to first reactivation was 58 days (range, 5-180 days) in the TCD group and 63 days (range, 2-107 days) in the non-TCD group (not significant). Plasma EBV-DNA levels measured at the peak of the first reactivation did not differ between the groups. Recurrent reactivation was significantly more frequent after TCD (Table 2): 14 of 85 patients (16\%) experienced multiple episodes of EBV reactivation after TCD-SCT, including 8 patients with 2 episodes, 5 patients with 3 episodes, and 1 patient showing 4 distinct periods of reactivation. This is exemplified for a recipient of a TCD donor graft who experienced 3 episodes of EBV reactivation without developing EBV-LPD (Figure 2). In contrast, only 2 of 65 patients $(3 \%)$ receiving non-TCD grafts had a second period of reactivation. ATG appeared not to be associated with recurrent reactivation, as only 2 of 14 patients with recurrent reactivation after TCD also received ATG as part of the conditioning regimen. Several risk factors predicted first reactivation in univariate analysis (Table 3$)$, including TCD $(P=.02)$, use of ATG in the conditioning regimen $(P<.001)$, transplantation of an unrelated donor graft $(P=.02)$, and a high $\mathrm{CD} 34^{+}$cell number of the graft $(P=.001)$ (Figure 3$)$. Following multivariate analysis, only the use of ATG and a high $\mathrm{CD} 34^{+}$cell count $\left(>1.35 \times 10^{6} /\right.$ $\mathrm{kg}$ ) remained independently associated with EBV reactivation (Table 3). Numbers of $\mathrm{CD}_{3} 4^{+}$and $\mathrm{CD} 3^{+}$cells were not associated with each other.

\section{EBV-LPD}

EBV-LPD was observed only after TCD-SCT (Table 2, Figure 4). Five patients developed EBV-LPD after HLA-identical sibling SCT and 5 after unrelated donor SCT (Table 4). Five of these patients had received ATG before unrelated donor SCT, and 9 of them had been treated for high-risk disease. All EBV-LPD donorrecipient pairs were EBV seropositive. One donor had negative EBV serology before transplantation. Median time from first reactivation to EBV-LPD was 22 days (range, 13-120 days) (Table 2). Median EBV-DNA level at EBV-LPD diagnosis was 110000

Table 2. Epstein-Barr virus (EBV) reactivation and EBV-lymphoproliferative disease

\begin{tabular}{|c|c|c|}
\hline Parameter & $\begin{array}{l}\text { T-cell-depleted allo-SCT } \\
\qquad(\mathrm{n}=85)\end{array}$ & $\begin{array}{l}\text { Unmanipulated allo-SCT } \\
\qquad(\mathrm{n}=65)\end{array}$ \\
\hline No. of patients with EBV reactivation (\%) & $46(54)$ & $18(28)$ \\
\hline Time (d) to first EBV reactivation (median, range) & $58(5-180)$ & $63(2-107)$ \\
\hline Maximum viral load $(\mathrm{gEq} / \mathrm{mL}$ ) of first EBV reactivation (median, range) & $535(50-3200000)$ & $808(55-540000)$ \\
\hline No. of patients (\%) with recurrent EBV reactivation & $14(16)$ & $2(3)$ \\
\hline No. of patients (\%) with EBV-LPD & $10(12)$ & - \\
\hline Time (d) from SCT to EBV-LPD (median, range) & $87(50-168)$ & - \\
\hline Time (d) from first EBV reactivation to EBV-LPD (median, range) & $22(13-120)$ & - \\
\hline EBV-LPD viral load (gEq/mL, median, range) & $110000(1800-790000)$ & - \\
\hline
\end{tabular}

$\mathrm{gEq} / \mathrm{mL}$ indicates genome equivalents of EBV DNA $/ \mathrm{mL}$. Other abbreviations are explained in Table 1. 
Table 3. Univariate and multivariate Cox regression analysis of risk factors for Epstein-Barr virus reactivation

\begin{tabular}{|c|c|c|c|c|c|c|}
\hline \multirow[b]{2}{*}{ Risk factor } & \multicolumn{3}{|c|}{ Univariate analysis } & \multicolumn{3}{|c|}{ Multivariate analysis } \\
\hline & $\mathrm{HR}$ & $95 \% \mathrm{Cl}$ & $P$ & HR & $95 \% \mathrm{Cl}$ & $P$ \\
\hline T-cell depletion, no ATG & 1.5 & $0.8-2.7$ & .02 & 1.5 & $0.8-2.9$ & .3 \\
\hline T-cell depletion, ATG & 3.5 & $1.8-6.9$ & $<.001$ & 3.4 & $1.6-7.1$ & .001 \\
\hline High-risk status & 1.6 & $1.0-2.8$ & .07 & 1.4 & $0.8-2.6$ & .2 \\
\hline Unrelated donor & 1.8 & $1.1-2.9$ & .02 & 0.9 & $0.3-2.9$ & .8 \\
\hline \multicolumn{7}{|c|}{$\mathrm{CD}_{34}{ }^{+}$cell count of the graft } \\
\hline$\left(>1.35 \times 10^{6} / \mathrm{kg}\right)$ & 2.4 & $1.4-4.1$ & .001 & 2.6 & $1.5-4.6$ & .001 \\
\hline
\end{tabular}

HR indicates hazard ratio; $\mathrm{Cl}$, confidence interval; ATG, antithymocyte globulin.

$\mathrm{gEq} / \mathrm{mL}$ (range, 1800-790 $000 \mathrm{gEq} / \mathrm{mL}$ ). Histologic proof of a diagnosis of EBV-LPD and classification according to the criteria of Knowles et al ${ }^{44}$ were obtained in 8 patients. Patient 8 (Table 4), who received an HLA-identical sibling SCT for multiple myeloma, was diagnosed with EBV-LPD by the presence of monoclonal B cells in his cerebrospinal fluid and an elevated plasma EBV-DNA level. Patient 9, who received an unrelated donor SCT because of SAA, was diagnosed with EBV-LPD because of massive lymphadenopathy on CT scanning and a highly elevated plasma EBV-DNA level. Six patients received anti-B-cell monoclonal antibody therapy (rituximab), 5 patients received DLI, and immune suppression was discontinued in 8 patients (Table 4). Five patients obtained a complete remission and 5 other patients died of progressive EBV-LPD. Two responding patients are currently alive with a follow-up of 620 and 351 days. Three responding patients developed severe GVHD, 2 following DLI, and died of GVHD-related complications. Use of ATG, application of TCD, and high-risk status of underlying disease significantly predicted EBV-LPD in univariate analysis. Multivariate analysis was not performed because the latter 3 variables appeared strongly associated and the small number of events did not allow a reliable multivariate analysis.

Several risk factors occurring after SCT were evaluated for a possible association with EBV-LPD by time-dependent analysis. A lower lymphocyte count at first EBV reactivation appeared not predictive for developing EBV-LPD. In contrast, EBV load significantly predicted EBV-LPD in a quantitative manner. A stepwise increase of EBV-DNA by $1 \log$ (Table 5) yielded a hazard ratio (HR) of 2.9 (95\% confidence interval [CI], 1.7-4.8) for those patients receiving a TCD graft $(P<.001)$. Numbers of patients with a TCD-SCT with plasma levels of EBV DNA exceeding a certain threshold value and the corresponding positive and negative

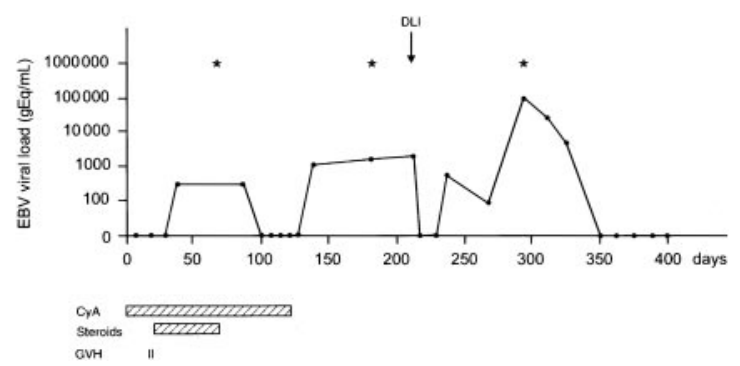

Figure 2. Monitoring EBV load after matched unrelated SCT. A 16-year-old EBV-seropositive male with a Philadelphia chromosome-positive $\left(\mathrm{Ph}^{+}\right) \mathrm{ALL}$ in first complete remission received a TCD matched unrelated donor graft from an EBV-seropositive donor. Multiple EBV reactivations were observed; however, no EBV-LPD ensued. Frequent examination of bone marrow for the presence of monoclonal $B$ cells and whole-body CT to detect lymphadenopathy were negative at various time points $\left({ }^{*}\right)$. At day 211 , DLI $\left(1.0 \times 10^{5} \mathrm{CD}^{+} \mathrm{T}\right.$ cells $\left./ \mathrm{kg}\right)$ was administered because of molecular relapse of his $\mathrm{Ph}^{+} \mathrm{ALL}$. Currently, the patient is free of disease and well at day 800 after SCT. CyA indicates cyclosporin A.

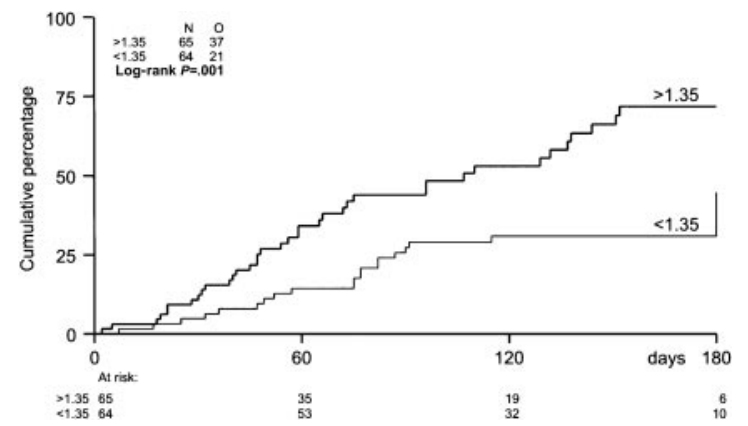

Figure 3. Incidence of EBV reactivation by number of $\mathrm{CD} 34^{+}$cells in the graft. The median number of CD34 $4^{+}$cells in the graft was $1.35 \times 10^{6} / \mathrm{kg}$. Patients with grafts containing more than $1.35 \times 10^{6} / \mathrm{kg}$ were at higher risk $(P=.001)$ of EBV reactivation.

predictive values for EBV-LPD for that subset of patients are shown in Table 5. Although the positive predictive value was $24 \%$ for patients with a copy number of $100 \mathrm{gEq} / \mathrm{mL}$ or higher, it rose to $100 \%$ at the level of $500000 \mathrm{gEq} / \mathrm{mL}$. However, only one patient with EBV-LPD reached that high number, and consequently the negative predictive value was $89 \%$.

\section{Graft-versus-host disease}

The actuarial probability of acute GVHD grade II to IV at day 100 was $57 \% \pm 4 \%$ for the whole group and was not significantly different for patients receiving a TCD graft as compared with patients receiving unmanipulated allo-SCT. An unrelated donor graft and a high $\mathrm{CD} 34^{+}$cell count of the graft (independent of the number of $\mathrm{CD}^{+} \mathrm{T}$ cells in the graft) were the only significant risk factors for developing acute GVHD following multivariate analysis. EBV reactivation was not associated with acute GVHD. Actuarial probabilities of chronic limited and extensive GVHD at 12 months after SCT were significantly higher for non-TCD patients $(83 \% \pm 5 \%)$ than for TCD patients $(38 \% \pm 6 \%)$ $(P<.001)$.

\section{Treatment-related mortality}

The actuarial probability of TRM was $29 \% \pm 4 \%$ at 1 year for all patients and did not differ between TCD and unmanipulated allo-SCT. Higher age and a higher $\mathrm{CD} 34^{+}$cell count $\left(>1.35 \times 10^{6} \%\right.$ $\mathrm{kg}$ ) of the graft predicted higher TRM in multivariate analysis. Following time-dependent analysis, EBV reactivation (HR 1.9; 95\% CI, 1.0-3.3; $P=.04$ ) and acute GVHD grade II to IV (HR 1.8;

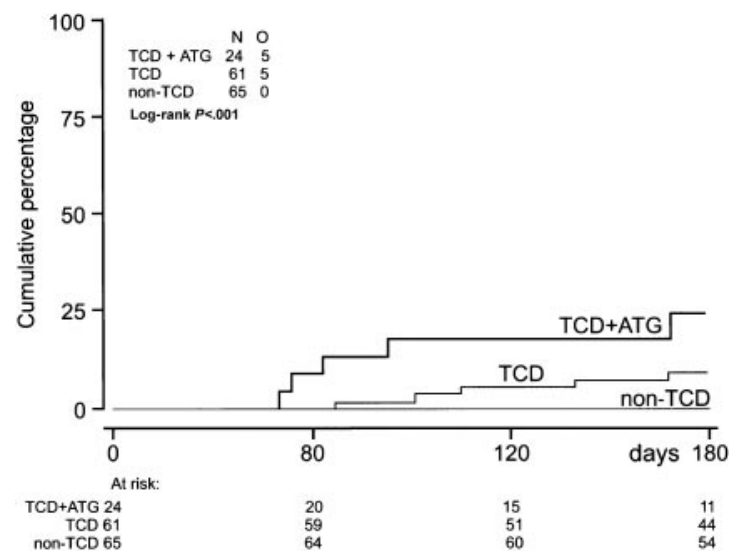

Figure 4. Incidence of EBV-LPD. Incidence of EBV-LPD $(n=10)$ after TCD allogeneic SCT combined with ATG $(n=24)$, TCD-SCT without ATG $(n=61)$, and non-TCD-SCT $(\mathrm{n}=65)$. 
Table 4. Epstein-Barr virus-lymphoproliferative disease following T-cell-depleted allo-SCT

\begin{tabular}{|c|c|c|c|c|c|c|c|c|c|c|}
\hline \multirow[b]{2}{*}{$\begin{array}{l}\text { Patient } \\
\text { no. }\end{array}$} & \multirow[b]{2}{*}{$\begin{array}{l}\text { Donor } \\
\text { type }\end{array}$} & \multicolumn{3}{|c|}{ EBV-LPD diagnosis } & \multicolumn{3}{|c|}{ Therapy } & \multicolumn{3}{|c|}{ Outcome } \\
\hline & & Morphology* & Clonality & $\begin{array}{c}\text { Plasma EBV } \\
\text { DNA (gEq/mL) }\end{array}$ & SI & $\begin{array}{l}\text { Anti- } \\
\text { CD20 }\end{array}$ & DLI & Response & Survival, d & COD \\
\hline 2 & MUD & II & Poly & 92000 & + & + & + & CR & Dead & GVHD \\
\hline 3 & MUD & II & Poly & 6500 & + & + & - & CR & Alive, 620+ & - \\
\hline 4 & Sib & III & Mono & 790000 & + & + & + & PD & Dead & EBV-LPD \\
\hline 6 & Sib & II & Mono & 74000 & + & + & - & $\mathrm{CR}$ & Dead & GVHD \\
\hline 7 & MUD & III & Mono & 133000 & + & + & + & PD & Dead & EBV-LPD \\
\hline 8 & Sib & ND & Mono & 7900 & + & - & - & PD & Dead & EBV-LPD \\
\hline 9 & MUD & ND & ND & 310000 & - & - & + & CR & Dead & GVHD \\
\hline 10 & MUD & III & Mono & 206000 & - & - & - & PD & Dead & EBV-LPD \\
\hline
\end{tabular}

$\mathrm{gEq} / \mathrm{mL}$ indicates genome equivalents of EBV DNA/mL; SI, stop immunosuppression; anti-CD20, monoclonal anti-B-cell therapy; DLI, donor lymphocyte infusion; COD, cause of death; Sib, HLA-identical family donor; Mono, monoclonal disease; PD, progressive disease; MUD, matched unrelated donor; Poly, polyclonal disease; CR, complete remission; GVHD, graft-versus-host disease; ND, not determined.

${ }^{*}$ I indicates plasma cell hyperplasia; II, polymorphic hyperplasia; III, non-Hodgkin lymphoma (criteria according to Knowles et al44).

95\% CI, 1.0-3.3; $P=.05)$ were associated with higher TRM. In addition, a higher lymphocyte count $\left(>0.6 \times 10^{9} / \mathrm{L}\right)$ at the time of first EBV reactivation significantly predicted less TRM (HR 0.3 ; 95\% CI, 0.1-0.8; $P=.02$ ).

\section{Discussion}

This study demonstrates that EBV reactivation is a very frequent event after both TCD and unmanipulated allo-SCT. In particular, recipients of stem cell grafts with high numbers of $\mathrm{CD} 34^{+} \mathrm{MNCs}$ appeared to be at risk for EBV reactivation. However, patients receiving a TCD-SCT were at significantly higher risk for recurrent reactivation, and only these patients developed EBV-LPD. The development of impending EBV-LPD in these patients could be predicted quantitatively by monitoring viral load in plasma at regular intervals during the first 6 months after SCT.

EBV reactivation was observed frequently after TCD-SCT and after unmanipulated allo-SCT as well. The high incidence of first EBV reactivation after TCD-SCT could be largely attributed to the use of ATG and, as a result, TCD per se did not appear to be an independent risk factor for early EBV reactivation. However, patients receiving a TCD-SCT showed more recurrence of reactivation, and EBV-LPD was observed only after TCD. Because the conditioning regimen has eradicated autologous EBV-specific immunity after both TCD and unmanipulated SCT, early EBV reactivation may occur after both modes of allo-SCT. ${ }^{50,51}$ However, the significantly higher risks for recurrent EBV reactivation and EBV-LPD in TCD-SCT as compared with unmanipulated SCT may be explained by the impaired capacity of patients receiving TCD grafts to mount an effective immune response to the reactivating

Table 5. Incidence of Epstein-Barr virus-lymphoproliferative disease by viral load following allogeneic T-cell-depleted SCT

\begin{tabular}{rcccc}
\hline \multirow{2}{*}{$\begin{array}{c}\text { EBV load } \\
(\mathrm{gEq} / \mathrm{mL})\end{array}$} & $\begin{array}{c}\text { No. of patients } \\
\text { with specified } \\
\text { reactivation }\end{array}$ & $\begin{array}{c}\text { No. of patients } \\
\text { with EBV-LPD }\end{array}$ & Positive (\%) & Negative (\%) \\
\cline { 4 - 5 } 100 & 41 & 10 & 24 & 100 \\
1000 & 26 & 10 & 39 & 100 \\
10000 & 14 & 7 & 50 & 96 \\
100000 & 7 & 5 & 71 & 94 \\
500000 & 1 & 1 & 100 & 89 \\
\hline
\end{tabular}

$\mathrm{gEq} / \mathrm{mL}$ indicates genome equivalents of EBV DNA $/ \mathrm{mL}$. Other abbreviations are explained in Table 1. virus. The strongly reduced numbers of EBV-specific memory $\mathrm{T}$ cells in TCD as compared with unmanipulated grafts may play a major role in this respect. ${ }^{52,53}$

Apart from the use of ATG as part of the conditioning regimen, we identified the number of $\mathrm{CD} 34^{+}$cells in the graft as a novel independent risk factor for developing EBV reactivation (Table 3, Figure 3), and also for acute GVHD and TRM. Przepiorka et $\mathrm{al}^{54}$ recently reported that recipients of peripheral blood stem cell grafts with high CD $34^{+}$cell counts were at higher risk for acute GVHD, an effect that appeared independent of the number of $\mathrm{CD}^{+} \mathrm{T}$ cells. They suggested that GVHD at high $\mathrm{CD}_{3} 4^{+}$cell doses may be exacerbated by cytokines released by the markedly expanding myeloid population at the time of engraftment. This explanation is supported by high levels of proinflammatory cytokines in patients with severe GVHD. ${ }^{55-57}$ In the present study, acute GVHD significantly predicted TRM in a time-dependent analysis. Therefore, the association of $\mathrm{CD}_{3} 4^{+}$cell dose and TRM might be explained by an increased incidence of GVHD. The association of CD $34^{+}$cell dose and EBV reactivation, however, is less likely to be explained by more GVHD, because EBV reactivation preceded the onset of acute GVHD in a significant number of patients. Alternative explanations may include infusion of a higher number of EBVinfected B cells together with larger stem cell grafts, or stimulation of B-cell proliferation by cytokines produced by the higher number of rapidly maturing myeloid progenitors. The latter explanation is supported by a number of preclinical as well as clinical studies showing that proinflammatory cytokines, such as interleukin-1 (IL-1), tumor necrosis factor- $\alpha$ and $-\beta$, and IL-6, may very effectively stimulate the growth of EBV-infected B cells. ${ }^{58}$ In particular, IL-6 may play an important role as a growth factor, promoting the progression toward overt EBV-LPD. ${ }^{59-62}$ Apart from monocyte-macrophages and endothelial cells as an established source of proinflammatory cytokines, the rapidly proliferating myeloid population of grafts containing high $\mathrm{CD}^{+} 4^{+}$cell doses may add to cytokine release and thus contribute to viral reactivation.

A number of studies have demonstrated a correlation between high levels of viral load and a diagnosis of EBV-LPD after both SCT and solid-organ transplantation. ${ }^{26-43}$ No study, however, has longitudinally followed allo-SCT recipients with multiple risk factors from day 0 until day 180 and reported positive and negative predictive values. Lucas et $\mathrm{al}^{41}$ evaluated the predictive value of quantitative PCR using DNA extracted from peripheral blood 
MNCs in a cohort of 195 patients receiving solid-organ transplantation. Although the negative predictive value appeared very high $(100 \%)$, the positive predictive value was $38 \%$. Our results observed in recipients of an allo-SCT are in line with these findings. Considering both TCD and non-TCD transplants, the negative and positive predictive values of a copy number of 1000 $\mathrm{gEq} / \mathrm{mL}$ were, respectively, $100 \%$ and $28 \%$. Higher predictive values were obtained when the analysis was restricted to patients receiving a TCD-SCT. The positive predictive values of a high EBV-DNA level of more than $1000 \mathrm{gEq} / \mathrm{mL}$ and more than 10000 $\mathrm{gEq} / \mathrm{mL}$ for patients receiving TCD-SCT were $39 \%$ and $50 \%$, respectively (Table 5).

Although highly significant, these predictive values also indicate that most patients (even recipients of TCD grafts) were able to mount an effective immune response and clear their viral reactivation. Monitoring of the reconstitution of HLA-specific T lymphocytes may add to the predictive value of viral load quantification. For this purpose, rapid assays are now available, such as the enumeration of $\mathrm{EBV}$-specific $\mathrm{T}$ lymphocytes by tetramer binding or the induction of intracellular interferon- $\gamma$ in T cells after specific stimulation. ${ }^{63}$ The accurate prediction of impending EBV-LPD in patients at risk is important because pre-emptive therapy might be more effective than therapy of established EBV-LPD. Despite the application of new treatment modalities such as DLI and anti-Bcell immunotherapy, the mortality of patients with established EBV-LPD is still high. Ten patients developed EBV-LPD in the present study: 5 died of progressive EBV-LPD and 3 patients died of GVHD following DLI, resulting in $80 \%$ (8 of 10) mortality.
Pre-emptive infusion of EBV-specific cytotoxic T cells has been shown to reduce viral load and may prevent the evolution toward EBV-LPD. ${ }^{20}$ However, the preparation and use of such EBVspecific $\mathrm{T}$ cells is expensive and difficult to implement on a wide scale. B-cell depletion of the donor graft has been shown to effectively reduce the incidence of EBV-LPD. ${ }^{7,16}$ Therefore, anti-Bcell immunotherapy aimed at in vivo B-cell depletion after SCT in patients at high risk of EBV-LPD might be a promising new means of pre-emptive therapy. A prospective phase II study with that specific aim is currently being performed. ${ }^{64}$ Because the depletion of B cells may further impair the immune status of these patients, one may argue to restrict pre-emptive therapy to those patients at highest risk. A threshold of $1000 \mathrm{gEq} / \mathrm{mL}$, as observed in our patient population, may thereby serve as a critical level of viral load to start pre-emptive therapy. Thus, pre-emptive therapy may be administered selectively to high-risk patients to prevent EBV-LPD and to avoid treatment of patients who have recovered their EBV-specific immunity to protective levels. The frequent monitoring of EBV load after allo-SCT may therefore be considered for patients with a high-risk profile for EBV-LPD and may preferably be combined with close monitoring of the reconstitution of EBV-specific T lymphocytes.

\section{Acknowledgments}

We thank Judith Guldemeester and Barbara Bruno for expert technical assistance and Janine Vrij for outstanding secretarial work.

\section{References}

1. Shapiro RS, McClain K, Frizzera G, et al. Epstein-Barr virus associated B cell lymphoproliferative disorders following bone marrow transplantation. Blood. 1988:71:1234-1243.

2. Zutter MM, Martin PJ, Sale GE, et al. EpsteinBarr virus lymphoproliferation after bone marrow transplantation. Blood. 1988;72:520-529.

3. Hanto DW, Frizzera G, Gajl-Peczalska KJ, Simmons RL. Epstein-Barr virus, immunodeficiency, and B-cell lymphoproliferation. Transplantation. 1985:39:461-472

4. Gross TG, Steinbusch M, DeFor T, et al. B cell lymphoproliferative disorders following hematopoietic stem cell transplantation: risk factors, treatment and outcome. Bone Marrow Transplant. 1999;23:251-258.

5. Micallef INM, Chhanabhai M, Gascoyne RD, et al. Lymphoproliferative disorders following allogeneic bone marrow transplantation: the Vancouver experience. Bone Marrow Transplant. 1998;22: 981-987.

6. Curtis RE, Travis LB, Rowlings PA, et al. Risk of lymphoproliferative disorders after bone marrow transplantation: a multi-institutional study. Blood. 1999:94:2208-2216.

7. Hale G, Waldmann H for CAMPATH Users. Risks of developing Epstein-Barr virus-related lymphoproliferative disorders after T-cell-depleted marrow transplants. Blood. 1998;91:3079-3080.

8. Walker RC, Marshall WF, Strickler JG, et al. Pretransplantation assessment of the risk of lymphoproliferative disorder. Clin Infect Dis. 1995;20: 1346-1353.

9. Fischer A, Blanche S, Le Bidois J, et al. Anti-Bcell monoclonal antibodies in the treatment of severe B-cell lymphoproliferative syndrome following bone marrow and organ transplantation. N Engl J Med. 1991:324:1451-1456.

10. Faye A, Van Den Abeele T, Peuchmaur M, Mathieu-Boue A, Vilmer E. Anti-CD20 monoclonal antibody for post-transplant lymphoproliferative disorders [letter]. Lancet. 1998;352:1285.
11. Milpied N, Vasseur B, Parquet N, et al. Humanized anti-CD20 monoclonal antibody (rituximab) in post transplant B-lymphoproliferative disorder: a retrospective analysis on 32 patients. Ann Oncol. 2000;11:S113-S116.

12. Kuehnle J, Huls MH, Lin Z, et al. CD20 monoclonal antibody (rituximab) for therapy of EpsteinBarr virus lymphoma after hemopoietic stem-cell transplantation. Blood. 2000;95:1502-1505.

13. Papadopoulos E, Ladanyi M, Emmanuel D, et al. Infusions of donor lymphocytes to treat EpsteinBarr virus-associated lymphoproliferative disorders after allogeneic bone marrow transplantation. N Engl J Med. 1994;330:1185-1191.

14. Heslop $\mathrm{HE}, \mathrm{Ng} \mathrm{CYC}, \mathrm{Li} \mathrm{C}$, et al. Long term restoration of immunity against Epstein-Barr virus infection by adoptive transfer of gene-modified virus-specific T lymphocytes. Nat Med. 1996;2:551 555

15. Rooney CM, Smith CA, Ng CYC, et al. Use of gene-modified virus-specific T lymphocytes to control Epstein-Barr-virus-related lymphoproliferation. Lancet. 1995;345:9-13.

16. Cavazzana-Calvo M, Bensoussan D, Jabado J et al. Prevention of EBV-induced B-lymphoproliferative disorder by ex vivo marrow B-cell depletion in HLA-phenoidentical or non-identical T-de pleted bone marrow transplantation. $\mathrm{Br} \mathrm{J}$ Haematol. 1998;103:543-551.

17. McDiarmid SV, Jordan S, Lee GS, et al. Prevention and pre-emptive therapy of posttransplant lymphoproliferative disease in pediatric liver recipients. Transplantation. 1998;66:1604-1611.

18. Green M, Kaufmann M, Wilson J, Reyes J. Comparison of intravenous ganciclovir followed by oral acyclovir with intravenous ganciclovir alone for prevention of cytomegalovirus and EpsteinBarr virus disease after liver transplantation in children. Clin Infect Dis. 1997;25:1344-1349.

19. Kuo PC, Dafoe DC, Alfrey EJ, Sibley RK, Scandling JD. Posttransplant lymphoproliferative disor- ders and Epstein-Barr virus prophylaxis. Transplantation. 1995;59:135-138.

20. Gustafsson A, Levitsky V, Zou JZ, et al. EpsteinBarr (EBV) load in bone marrow transplant recipients at risk to develop posttransplant lymphoproliferative disease: prophylactic infusion of EBVspecific cytotoxic T cells. Blood. 2000;95:807814.

21. Davis CL, Harrison KL, McVicar JP, Forg PJ, Bronner MP, Marsh CL. Antiviral prophylaxis and the Epstein-Barr virus-related post-transplant lymphoproliferative disorder. Clin Transplant. 1995;9:53-59.

22. Trigg ME, Finlay JL, Sondel PM. Prophylactic acyclovir in patients receiving bone marrow transplants [letter]. N Engl J Med. 1985;26:1708-1709.

23. Darenkov IA, Marcarelli MA, Basadonna GP, et al. Reduced incidence of Epstein-Barr virus-associated posttransplant lymphoproliferative disorder using pre-emptive antiviral therapy. Transplantation. 1997;64:848-852.

24. Green M, Reyes T, Jabbour N, et al. Use of quantitative PCR to predict onset of Epstein-Barr viral infection and post-transplant lymphoproliferative disease after intestinal transplantation in children. Transplant Proc. 1996;28:2759-2760.

25. Niesters HGM, Van Esser J, Fries E, et al. Development of a real-time quantitative assay for detection of Epstein-Barr virus. J Clin Microbiol. 2000;38:712-715.

26. Van Esser JWJ, Niesters HGM, Thijsen SFT, et al. Molecular quantitation of viral load in plasma allows for fast and accurate prediction of response to therapy of Epstein-Barr virus-associated lymphoproliferative disease after allogeneic stem cell transplantation. $\mathrm{Br} \mathrm{J}$ Haematol. 2001; 113:814-821.

27. Lucas KG, Burton RL, Zimmerman SE, et al. Semiquantitative Epstein-Barr virus (EBV) polymerase chain reaction for the determination of 
patients at risk for EBV-induced lymphoproliferative disease after stem cell transplantation. Blood. 1998;91:3654-3661.

28. Savoie A, Perpête C, Carpentier L, Joncas J, Alfieri C. Direct correlation between the load of Epstein-Barr virus-infected lymphocytes in the peripheral blood of pediatric transplant patients and risk of lymphoproliferative disease. Blood. 1994; 83:2715-2722.

29. Beck R, Westdörp I, Jahn G, Schäfer H, Kanz L Einsele H. Detection of Epstein-Barr virus DNA in plasma from patients with lymphoproliferative disease after allogeneic bone marrow transplantation or peripheral blood stem cell transplantation [letter]. J Clin Microbiol. 1999;37:3430-3431.

30. Limaye AP, Huang M-L, Atienza EE, Ferrenberg JM, Corey L. Detection of Epstein-Barr virus DNA in sera from transplant recipients with lymphoproliferative disorders. J Clin Microbiol. 1999;37: 1113-1116.

31. Rooney CM, Loftin SK, Holladay MS, Brenner MK, Krance RA, Heslop HE. Early identification of Epstein-Barr virus-associated post-transplantation lymphoproliferative disease. Br J Haematol. 1995;89:98-103.

32. Hoshino Y, Kimura H, Kuzushima K, et al. Early intervention in post-transplant lymphoproliferative disorders based on Epstein-Barr viral load. Bone Marrow Transplant. 2000;26:199-201.

33. Rowe DT, Qu L, Reyes N, et al. Use of quantitative competitive PCR to measure Epstein-Barr virus genome load in the peripheral blood of pediatric transplant patients with lymphoproliferative disorders. J Clin Microbiol. 1997;35:1612-1615.

34. Kenagy DN, Schlesinger Y, Weck K, Ritter JH, Gaudreault-Keener MM, Storch GA. Epstein-Barr virus DNA in peripheral blood leucocytes of patients with posttransplant lymphoproliferative disease. Transplantation. 1995;60:547-554.

35. Telenti A, Marshall WF, Smith TF. Detection of Epstein-Barr virus by polymerase chain reaction. J Clin Microbiol. 1990;28:2187-2190.

36. Yamamoto M, Kimura H, Hironaka T, et al. Detection and quantification of virus DNA in plasma of patients with Epstein-Barr virus associated diseases. J Clin Microbiol. 1995;33:1765-1768.

37. Kimura H, Morita M, Yabuta Y, et al. Quantitative analysis of Epstein-Barr virus load by using a real-time PCR assay. J Clin Microbiol. 1999;37: 132-136.

38. Riddler SA, Breinig MC, McKnight LC. Increased levels of circulating Epstein-Barr virus (EBV)-infected lymphocytes and decreased EBV nuclear antigen antibody responses are associated with the development of posttransplant lymphoproliferative disease in solid-organ transplant recipients. Blood. 1994;84:972-984.
39. Green M, Cacciarelli TV, Mazariegos GV, et al. Serial measurement of Epstein-Barr viral load in peripheral blood in pediatric liver transplant recipients during treatment for posttransplant lymphoproliferative disease. Transplantation. 1998; 66:1641-1644.

40. Barkholt LM, Dahl H, Enbom N, Lindé A. EpsteinBarr virus DNA in serum after liver transplantation-surveillance of viral activity during treatment with different immunosuppressive agents. Transpl Int. 1996;9:439-445.

41. Lucas KG, Filo R, Heilman DK, Lee CH, Emmanuel DJ. Semiquantitative Epstein-Barr virus polymerase chain reaction analysis of peripheral blood from organ transplant patients at risk for the development of lymphoproliferative disease [letter]. Blood. 1998;92:3977-3978.

42. Krieger NR, Martinez OM, Krams SM, Cox K, So $\mathrm{S}$, Esquivel CO. Significance of detecting Epstein-Barr-specific sequences in the peripheral blood of asymptomatic pediatric liver transplant recipients. Liver Transpl. 2000;6:62-66.

43. Baldanti F, Grossi P, Furione M, et al. High levels of Epstein-Barr virus DNA in blood of solid organ transplant recipients and their value in predicting posttransplant lymphoproliferative disorders. J Clin Microbiol. 2000;38:613-619.

44. Knowles DM, Cesarman E, Chadburn A, et al. Correlative morphologic and molecular genetic analysis demonstrates three distinct categories of posttransplantation lymphoproliferative disorders. Blood. 1995;85:552-565.

45. Przepriorka D, Weisdorf D, Martin P, et al. 1994 consensus conference on acute GVHD grading. Bone Marrow Transplant. 1995;15:825-829.

46. Clift R, Goldman J, Gratwohl A, Horowitz M. Proposals for standardized reporting of results of bone marrow transplantation for leukemia. Bone Marrow Transplant. 1989;4:445-451.

47. Kaplan EL, Meier P. Nonparametric estimation for incomplete observations. J Am Stat Assoc. 1958; 53:457-481

48. Mantel N. Evaluation of survival data and two new rank order statistics arising in its consideration. Cancer Chemother Rep. 1966:50:163-170.

49. Cox DR. Regression models and life-tables (with discussion). J R Stat Soc B. 1972;34:187-220.

50. Gratama JW, Oosterveer MAP, Zwaan FE, Lepoutre J, Klein G, Ernberg I. Eradication of Epstein-Barr virus by allogeneic bone marrow transplantation: implications for sites of viral latency. Proc Natl Acad Sci U S A. 1988;85:8693-8696.

51. Gratama JW, Oosterveer MAP, Lepoutre JMM, et al. Serologic and molecular studies of EpsteinBarr virus infection in allogeneic marrow graft recipients. Transplantation. 1990;49:725-730.
52. Lucas KG, Small TN, Heller G, Dupont B, O'Reilly $\mathrm{RJ}$. The development of cellular immunity to Epstein-Barr virus after allogeneic bone marrow transplantation. Blood. 1996;87:2594-2603.

53. Rickinson AB, Moss DJ. Human cytotoxic T lymphocyte responses to Epstein-Barr virus infection. Annu Rev Immunol. 1997;15:405-431.

54. Przepiorka D, Smith TL, Folloder J, et al. Risk factors for acute graft-versus-host disease after allogeneic blood stem cell transplantation. Blood. 1999;94:1465-1470.

55. Ferrara JL. Cytokine inhibitors and graft-versushost disease. Ann N Y Acad Sci. 1995;770:227236.

56. Rus V, Svetic A, Nguyen P, et al. Kinetics of Th1 and Th2 cytokine production during the early course of acute and chronic murine graft-versushost disease. Regulatory role of donor $\mathrm{CD}^{+} \mathrm{T}$ cells. J Immunol. 1995;155:2396-2406.

57. Hill GR, Crawford JM, Cooke JR, et al. Total body irradiation and acute graft-versus-host disease: the role of gastrointestinal damage and inflammatory cytokines. Blood. 1997;90:3204-3213.

58. Tosato G, Teruya-Feldstein J, Setsuda J, et al. Post-transplant lymphoproliferative disease (PTLD): lymphokine production and PTLD. Springer Semin Immunopathol. 1998;20:405-423.

59. Tosato G, Tanner J, Jones KD, Revel M, Pike SE. Identification of interleukin- 6 as an autocrine growth factor for Epstein-Barr virus-immortalized B-cells. J Virol. 1990;64:3033-3041.

60. Scala G, Quinto I, Ruocco MR, et al. Expression of an exogenous interleukin 6 gene in human Epstein Barr virus $B$ cells confers growth advantage and in vivo tumorigenicity. J Exp Med. 1990;172: 61-68.

61. Tosato G, Jones KD, Breinig MK, McWilliams HP, McKnight JLC. Interleukin-6 production in posttransplant lymphoproliferative disease. J Clin Invest. 1993;91:2806-2814.

62. Jones K, Rivera C, Sgadari C, et al. Infection of human endothelial cells with Epstein-Barr virus. J Exp Med. 1995;182:1213-1221.

63. Marshall NA, Howe JG, Formica R, et al. Rapid reconstitution of Epstein-Barr virus-specific T lymphocytes following allogeneic stem cell transplantation. Blood. 2000;96:2814-2821.

64. Cornelissen JJ, Van Esser JWJ, Van Der Holt B, et al. Pre-emptive anti B-cell immunotherapy guided by quantitative PCR effectively reduces the incidence and mortality of Epstein-Barr virus (EBV) lymphoproliferative disease (LPD) after allogeneic T-cell-depleted (TCD) stem cell transplantation (SCT) [abstract]. Blood. 2000;96:507a. 